\title{
A preliminary investigation on the cyclomorphosis of Daphnia gessneri Herbst, 1967, in a Brazilian reservoir
}

\author{
MARLENE SOFIA ARCIFA ZAGO
}

\section{A B S T R A C T}

The cyclomorphosis of a natural population of Daphnia (D. gessneri Herbst, 1967 ) in Americana Reservoir (Brazil) is investigated during one year.

The structures considered were helmet, head basis, carapace and spine of carapace, measured in two instars: newborn and last stage adult. The relative length of the helmet and of the spine showed variation in time, with summer increment, while the head basis showed a less expressive variation.

Three environmental factors were considered: temperature, turbulence and nutrition. There are no linear correlation between the ratios helmet/carapace, spine/carapace and the temperature, but the latter seems to have influenced above a limit $\left(25^{\circ} \mathrm{C}\right)$. Nutrition, estimated indirectly through the egg production, seems to have affected the proportions, but the cyclical variation of food is difficult to evidence in the environment. It is possible that the relative length of the mentioned structures was influenced by the joint action of the three factors.

The eye size was also considered, being smaller in the low helmeted form.

\section{N T R O D U C T I O N}

The cyclomorphosis in Cladocera, mainly in species of Daphnia, was investigated in detail in temperate regions. In tropical and subtropical ones, generally speaking, observations withouth mensuration data were made.

The investigations, based on laboratory populations, natural populations, or both, have searched the causes and the adaptive value of cyclomorphosis. The environmental factors more intensely investigated as possible causes were: temperature (Ostwald, 1904; Wesenberg-Lund, 1926; Coker and Addlestone, 1938; Brooks, 1946; Jacobs, 1961a; Hazelwood, 1962, and Egloff, 1968), turbulence (Brooks, 1947; Hrbácek, 1959, and Jacobs, 1961a), turbulence allied to light (Jacobs, 1962, and Hazel- 
wood, 1966), and nutrition (Coker and Addlestone, 1938; Brooks, 1946, and Jacobs, 1961a).

The adaptative value is still a very discussed theme. The hypotheses are concerned with density and viscosity of the water and the buoyancy of the organisms, defended by Ostwald and Wesenberg-Lund; with stabilization and direction of the animal (Woltereck, 1909); with predation (Brooks, 1965; Green, 1967; Jacobs, 1967, and Dodson, 1974). It was even suggested that this variation of form has no adaptive meaning, although Jacobs (1961b) searched to prove the contrary.

This paper deals with an attempt to verify the occurrence of cyclomorphosis in a species in tropical conditions and to test the factors known as important in the process in temperate zones. The lack of knowledge on the subject in tropical regions makes it exceedingly hard to extend the conclusions from researches in temperate regions to our latitudes.

In this work an analysis is done of the monthly variation of the relative length of the head (divided in two parts) and of the spine of the carapace of Daphnia gessneri in two instars - newborn and adult during one year (with a gap of two months). The factors to which the structure are related are: temperature, turbulence and nutrition. The results, however, are preliminary and intend to be a basis for further studies.

I would like to express my deepest thanks to Dr. Claudio G. Froehlich, Dr. Antonio Carlos Azevedo and Miss Gisela Y Shimizu.

\section{MATERIAL AND METHODS}

Americana Reservoir is located in São Paulo State, Brazil, 2244'20" S Latitude and $49^{\circ} 19^{\prime} 52^{\prime \prime}$ W Longitude.

The samples were collected monthly at Station 6 (see Zago, 1976) from June, 1969 to June, 1970. Sampling was made with a net $85 \mu \mathrm{m}-$ meshed through vertical hauls.

In the present work the attempt to utilize the allometric analysis introduced by Brooks (1946) failed, for $\mathrm{k}$ is not constant through the instars. In such case, two stages were chosen: newborn and last stage adult.

From each sample 36 newborn and 50 egged parthenogenetic females were measured. Each specimen was measured in profile, at the microscope with the help of a camera lucida. The eggs were counted and the averages of eggs per adult were computed.

In fig. 1 , the measured regions are delimited by parallel lines. The head is divided in two parts (according to Jacobs, 1961b): the helmet (E), delimited by the apex of the head and the anterior limit of eye pigmentation, and the basal part (B), whose posterior delimitation 
is the tangent to the head limit. The carapace (C) is posteriorly limited by the line that passes by the end of the opening of the carapace, shown in the same figure. The spine (S) is measured from this line to the end.

The length of the measured structures - helmet, basis of head and spine - was related to the carapace length $-E / C, B / C$ and $S / C$. The average, the standard deviation and the confidence interval $(95 \%)$ were calculated for each sample.

The temperature values represent averages from superficial and deep water temperatures.

The eye, from last instar aduits, was measured according to Zaret (1972) at the microscope with a camera lucida. Twenty specimens were obtained from the samples of 25/9/69 and 28/1/70.

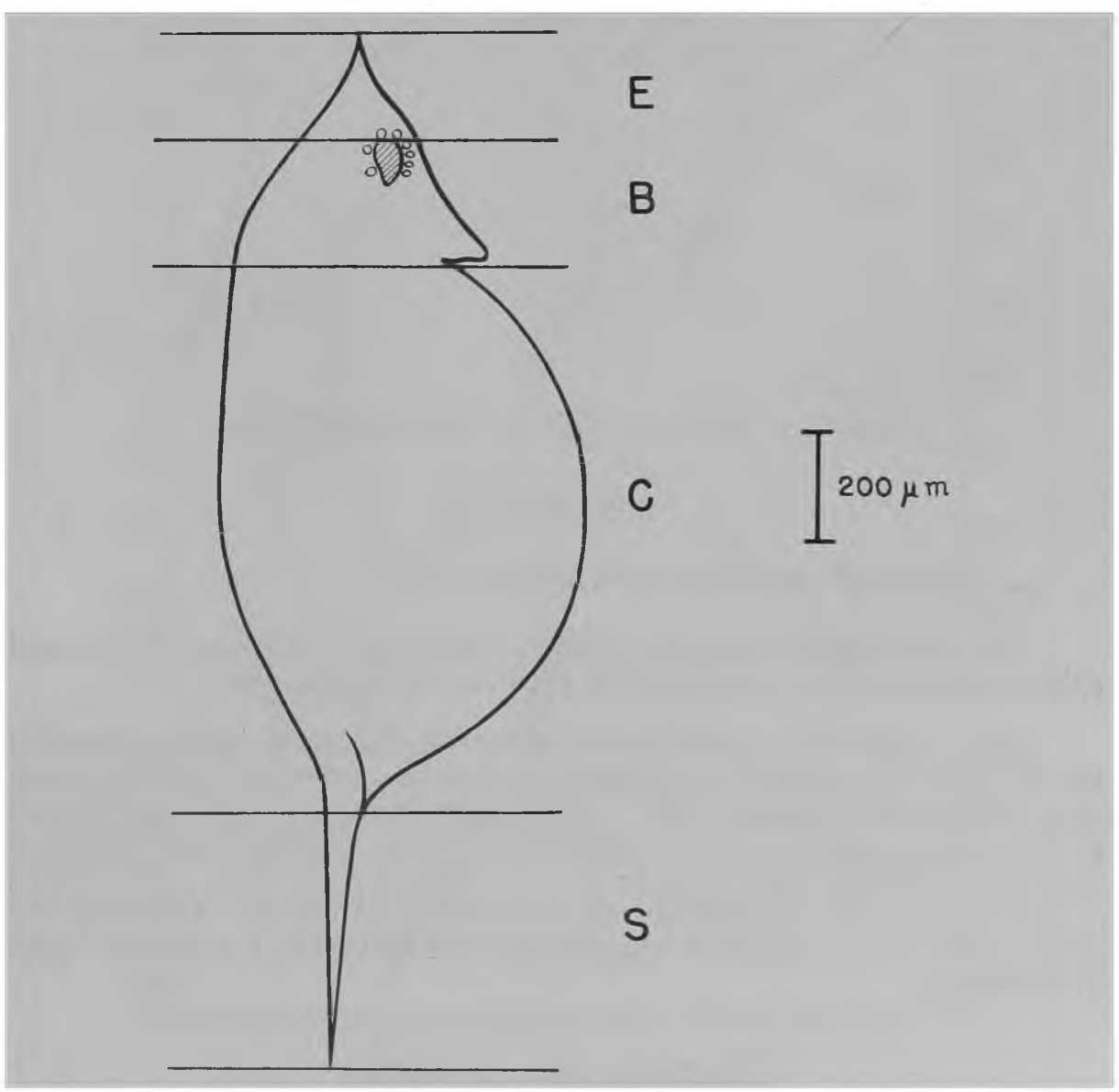

Fig. 1 - Outline of adult female of Daphnia gessneri, in profile, showing the measured regions. $\mathrm{E}-$ Helmet; $\mathrm{B}-$ Basal part of head; C - Carapace; $S-$ Spine of carapace. 


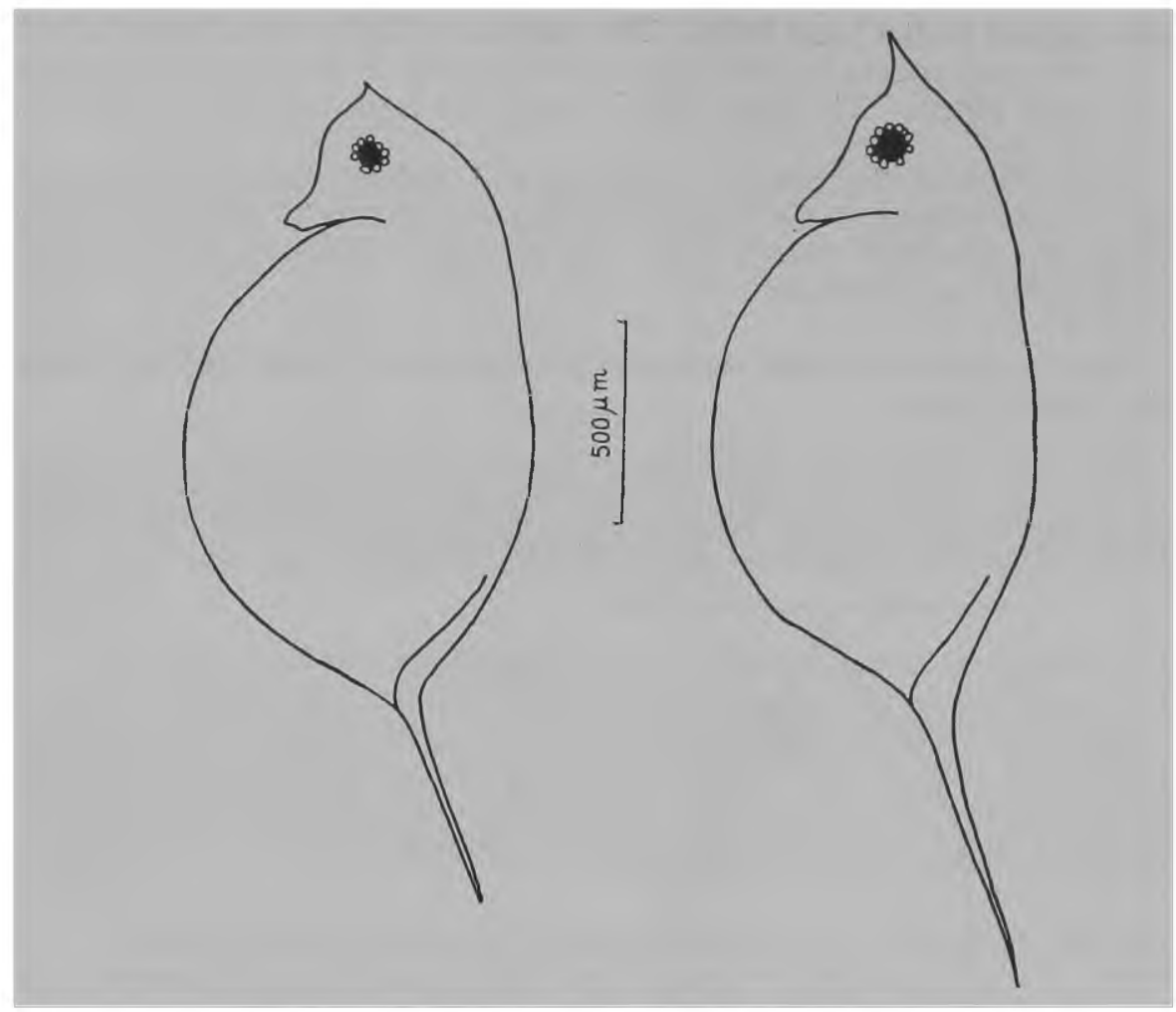

Fig. 2 - Outlines of high and low helmeted forms.

\section{RES U L T S}

a. Seasonal variation in the newborn

The ratio helmet/carapace $(\mathrm{E} / \mathrm{C})$, head basis/carapace $(B / C)$, and spine/carapace $(\mathrm{S} / \mathrm{C})$ reflects the prenatal relative growth.

Fig. 3 shows the variations of the ratio averages, being noticeable the fall of E/C and S/C in July and September, followed by an increase that culminates in January, 28. In the same figure a similar development of these two curves can be noticed, there being positive and significant correlation between them (fig. $4 ; \mathrm{r}=+0.83, \mathrm{p}<0.001$ ). $\mathrm{B} / \mathrm{C}$ shows a pronounced fall in September like the other two curves. Generally the development of $\mathrm{B} / \mathrm{C}$ is more irregular and the curve has a narrower range of variation.

\section{Correlation with temperature}

The embryonic development in laboratory conditions at an average temperature of $21^{\circ} \mathrm{C}$, has taken about 3 days. So, it is possible to assume 
that in the environment, the newborns had developed a few days before sampling. This stage is, then, the nearest to the environmental data obtained at the moment of sampling.

In the relationship of the ratios $\mathrm{E} / \mathrm{C}, \mathrm{B} / \mathrm{C}$ and $\mathrm{S} / \mathrm{C}$ with the instantaneous temperatures (figs. $5 \mathrm{~A}, \mathrm{~B}, \mathrm{C}$ ) the points are scattered. The correlation coefficients $(\mathrm{r}=+0.19, \mathrm{r}=+0.30$ and $\mathrm{r}=+0.30$, respectively) are not significant $(\mathrm{p}>0.1)$.

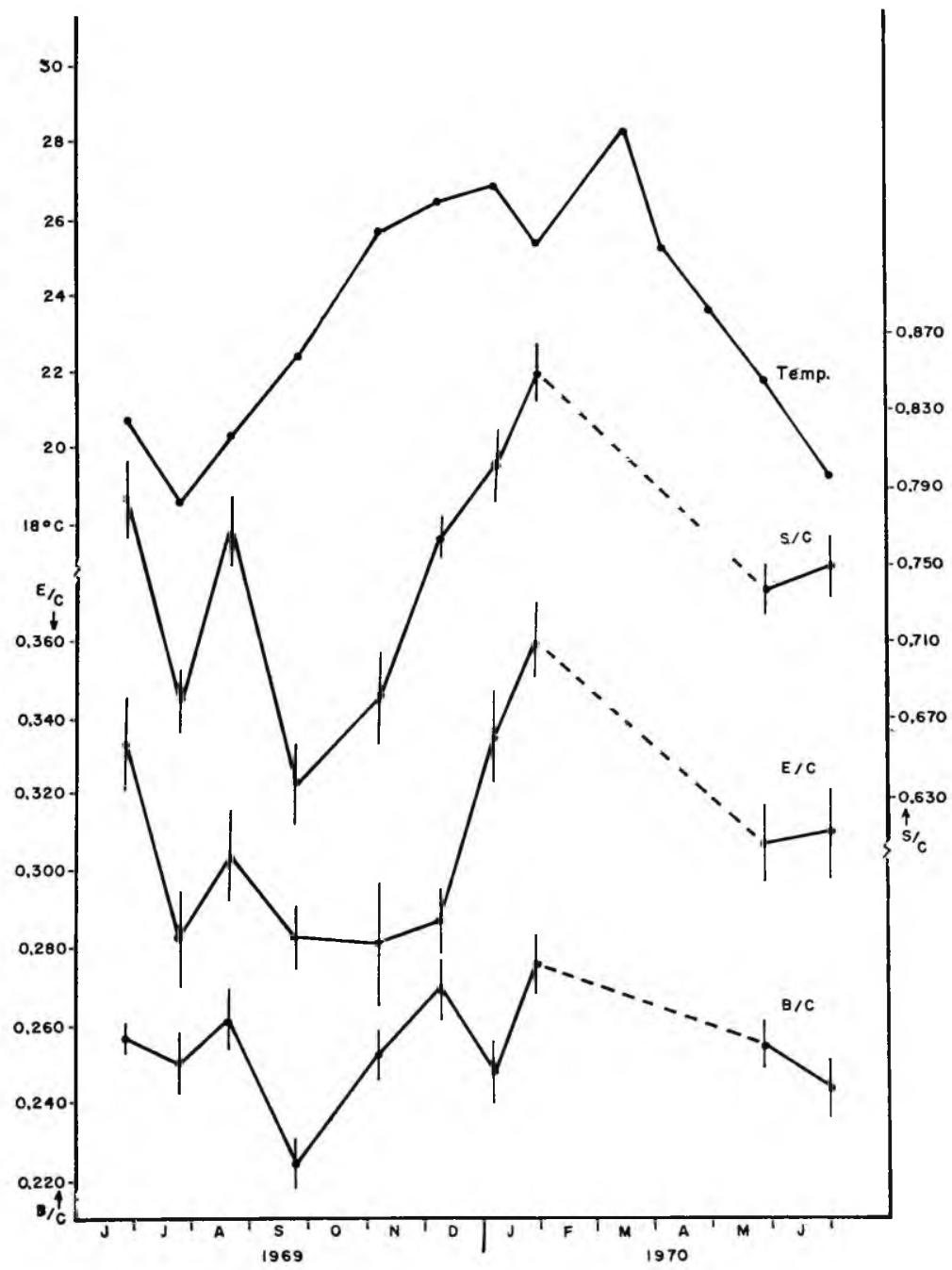

Fig. 3 - Variation of temperature and of $E / C, B / C$ and $S / C$ in the newborns. Solid circles represent the means. 


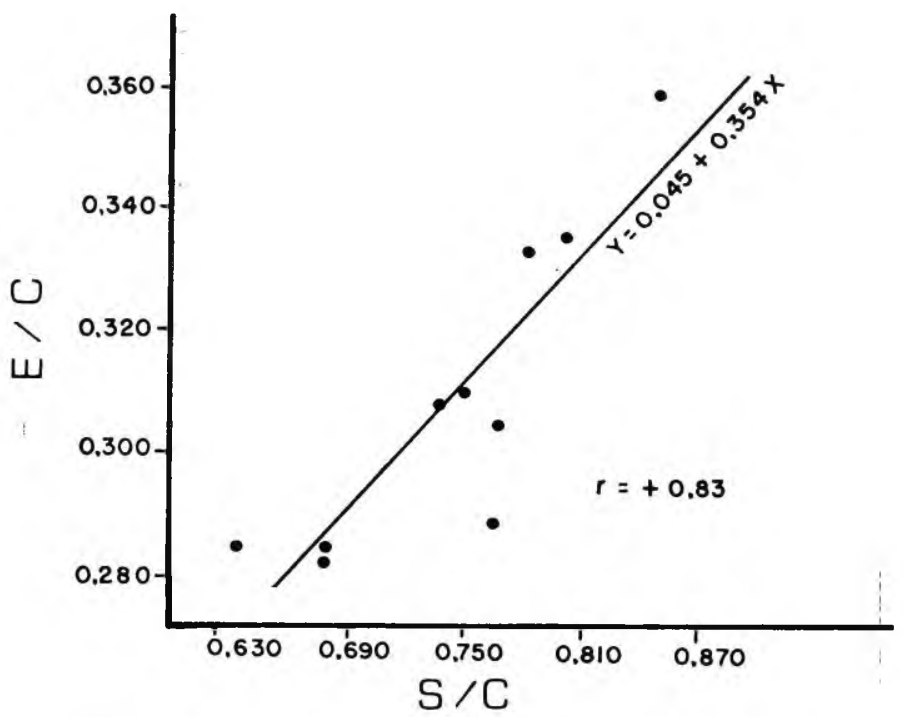

Fig. 4 - Regression of $E / C$ on $S / C$ in the newborns.

\section{Correlation with nutrition}

It is difficult to establish directly the nutritional state of the animals in natural conditions. Assuming that the adults spend a great amount of energy in reproduction, the nutritional state could be estimated through the numbers of eggs produced.

The nutritional condition of the female can affect the size of the newborn (Green, 1956). Thus, E/C, B/C and S/C were related to the average number of eggs per ađult. There is linear correlation between $\mathrm{E} / \mathrm{C}, \mathrm{S} / \mathrm{C}$ and the number of eggs $(\mathrm{r}=+0.74,0.001<\mathrm{p}<0.01)$ in both cases (figs. 6A, C). There is no linear correlation between $\mathrm{B} / \mathrm{C}$ and the number of eggs, $(r=+0.30, p>0.1$; fig. $6 B)$.

\section{b. Seasonal variation in the adult}

The ratios $\mathrm{E} / \mathrm{C}, \mathrm{B} / \mathrm{C}$ and $\mathrm{S} / \mathrm{C}$ point out the postnatal relative growth.

Observing fig. 7 , a similar trend is noticeable in the development of the curves $\mathrm{E} / \mathrm{C}$ and $\mathrm{S} / \mathrm{C}$ and the newborn $\mathrm{E} / \mathrm{C}$ and $\mathrm{S} / \mathrm{C}$. The range of variation of $\mathrm{B} / \mathrm{C}$ is narrower than in the newborns, only the fall in September being proeminent.

$\mathrm{E} / \mathrm{C}$ and $\mathrm{S} / \mathrm{C}$ show a similar pattern, there being a positive and significant linear correlation between them (fig. $8 ; \mathrm{r}=+0.64$, $0.02<\mathrm{p}<0.05)$.

\section{Correlation with temperature}

Actually the adults were subject to a greater range of temperature, than that shown by the instantaneous values. However, as intermediate values were not available the instantaneous ones were used, by necessity. 

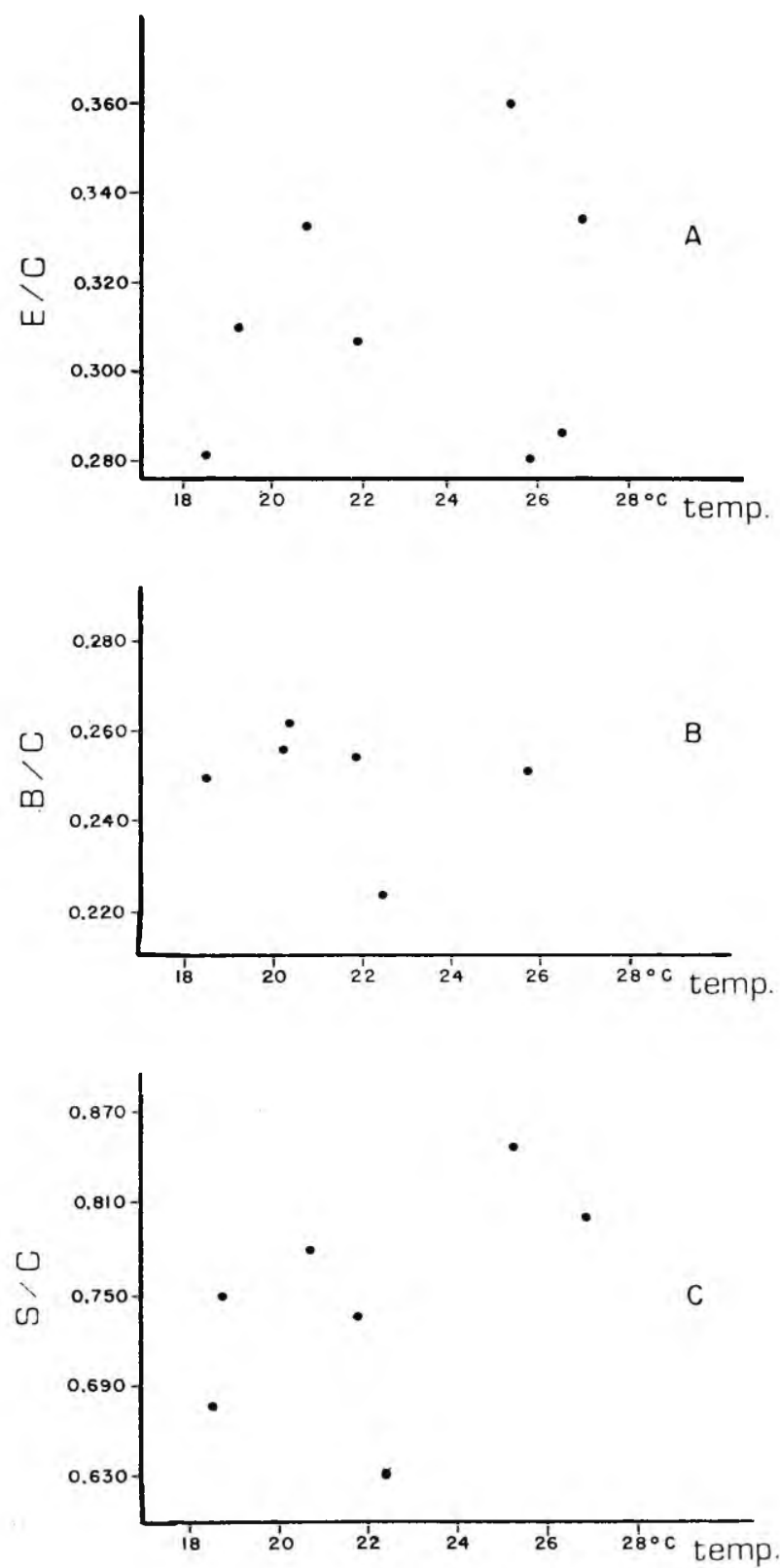

Figs. 5A, B, C - The relationship between $\mathrm{E} / \mathrm{C}, \mathrm{B} / \mathrm{C}$ and $\mathrm{S} / \mathrm{C}$ in the newborns, respectively, and the temperature. 

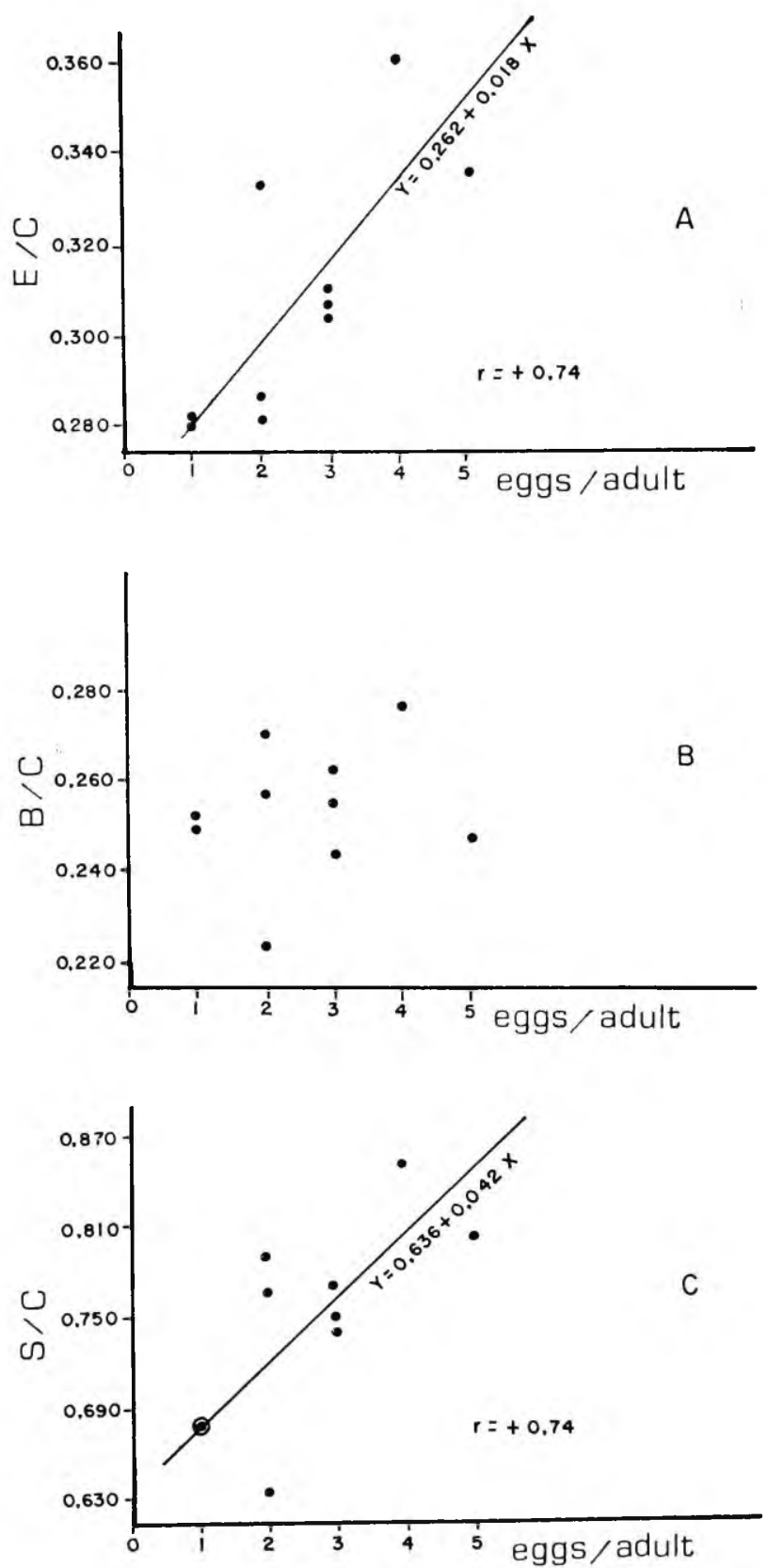

Figs. $6 \mathrm{~A}, \mathrm{~B}, \mathrm{C}-$ The regression of $\mathrm{E} / \mathrm{C}, \mathrm{B} / \mathrm{C}$, and $\mathrm{S} / \mathrm{C}$ in the newborns, respectively, on the number of eggs per adult. 


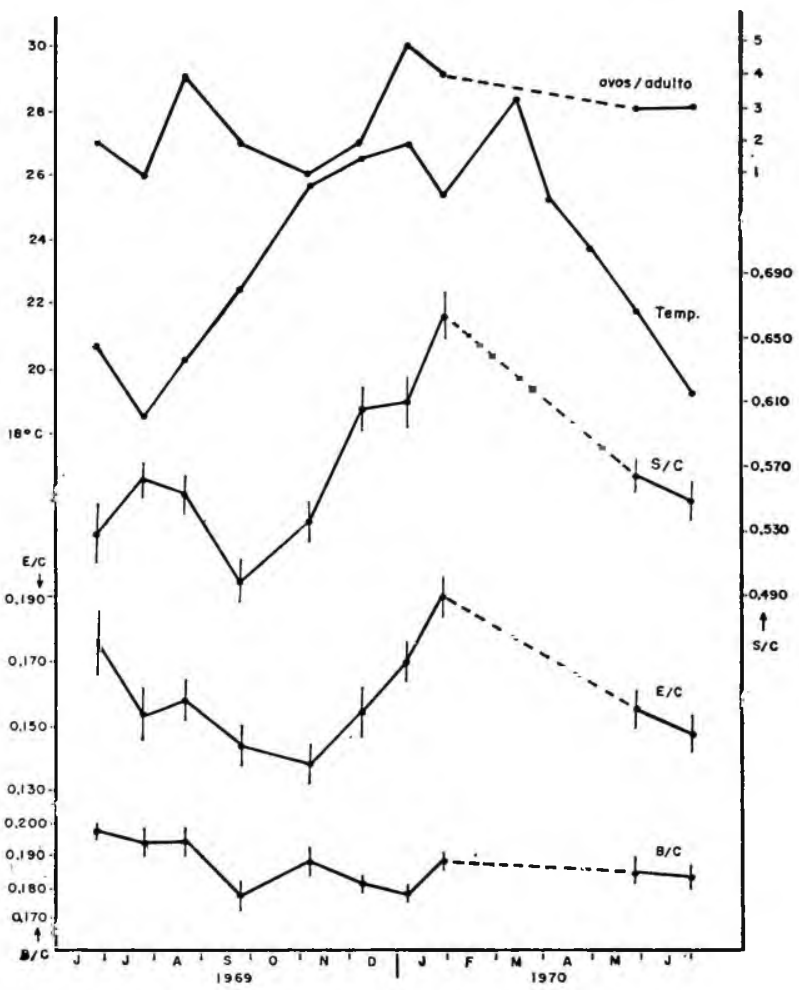

Fig. 7 - Variation of temperature, of number of eggs per adult and of $E / C, B / C$, $\mathrm{S} / \mathrm{C}$ in the adults. Solid circles represent the means.

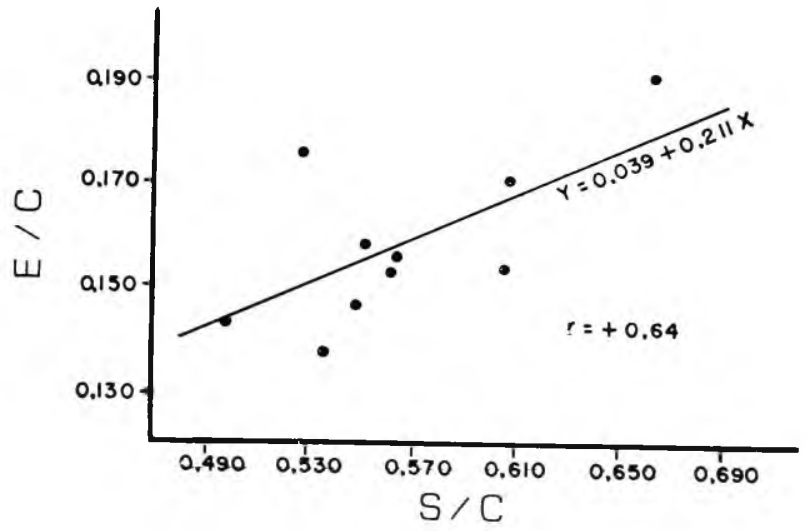

Fig. 8 - Regression of $\mathrm{E} / \mathrm{C}$ on $\mathrm{S} / \mathrm{C}$ in the adults. 

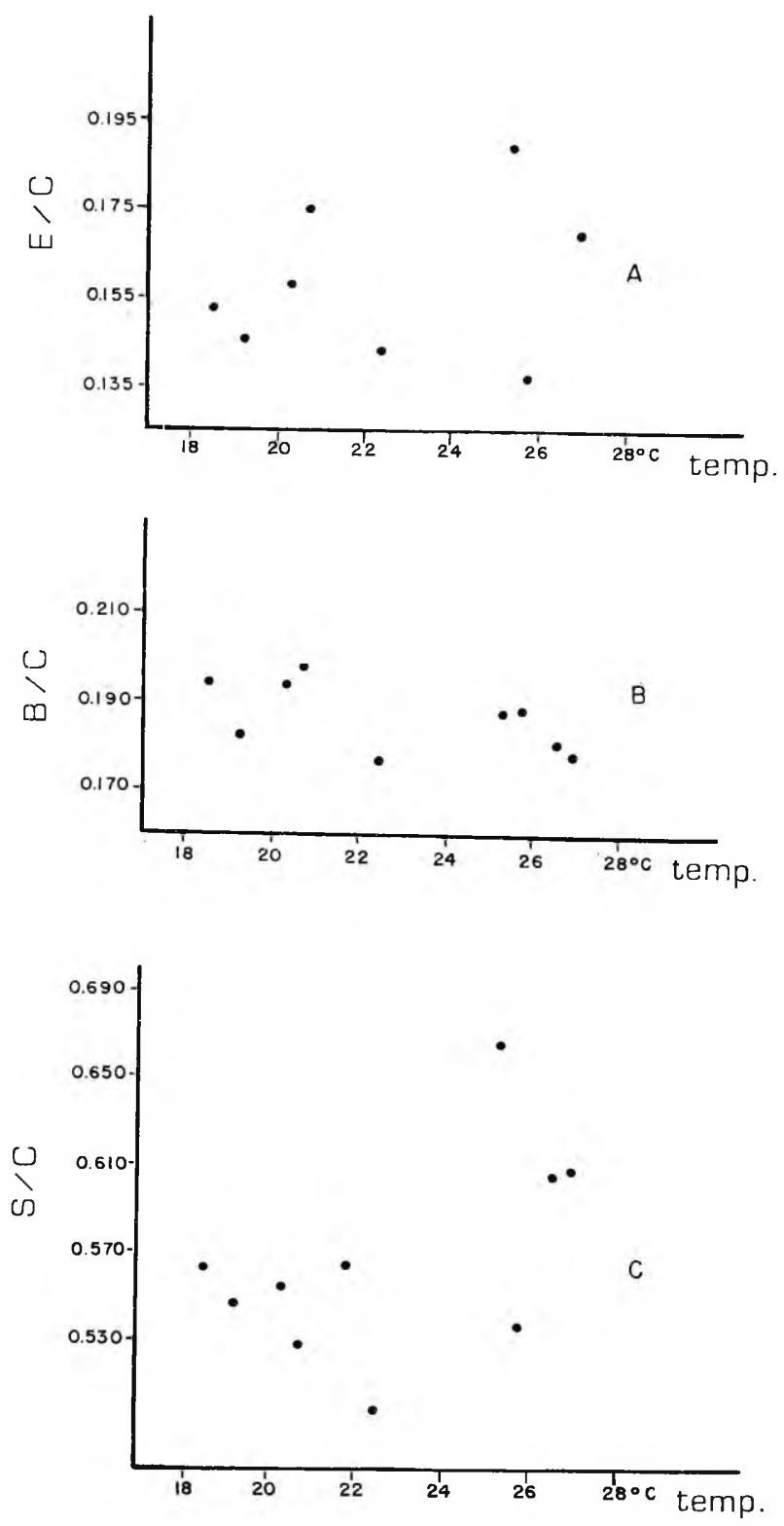

Figs. 9A, B, C - The relationship between $\mathrm{E} / \mathrm{C}, \mathrm{B} / \mathrm{C}$ and $\mathrm{S} / \mathrm{C}$ in the adults, respectively, and the temperature.

There is no correlation between $\mathrm{E} / \mathrm{C}, \mathrm{B} / \mathrm{C}, \mathrm{S} / \mathrm{C}$ and the temperatures: $r=+0.20(p>0.1), r=+0.52(0.05<p<0.1)$ and $\mathrm{r}=+0.52(0.05<\mathrm{p}<0.1)$, respectively (figs. $9 \mathrm{~A}, \mathrm{~B}, \mathrm{C}$ ). 

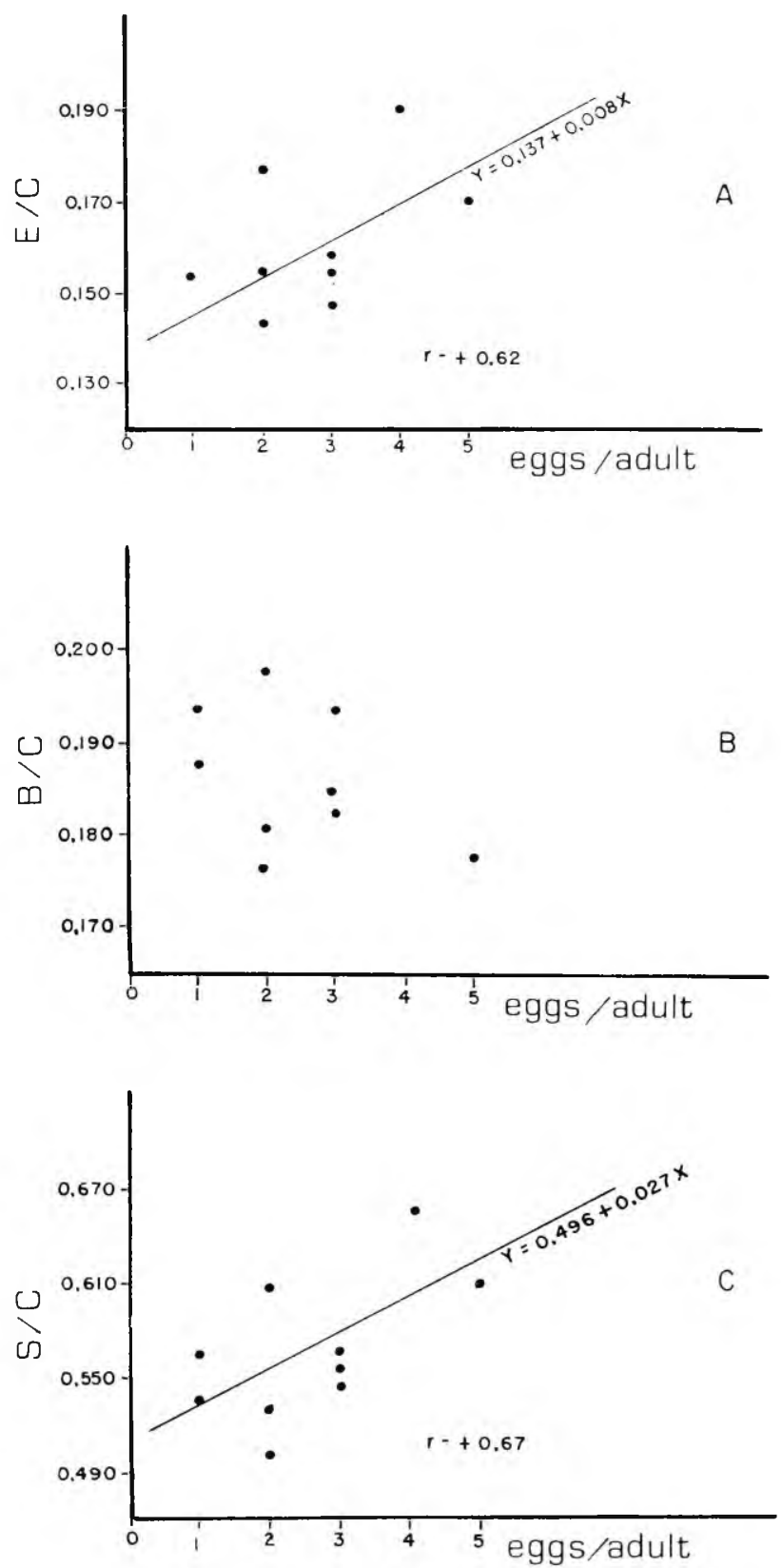

Figs. 10A, B, C - Regression of $\mathrm{E} / \mathrm{C}, \mathrm{B} / \mathrm{C}$ and $\mathrm{S} / \mathrm{C}$ in the adults, respectively, on the number of eggs per adult. 


\section{Correlation with nutrition}

The correlation between $\mathrm{E} / \mathrm{C}, \mathrm{S} / \mathrm{C}$ and the number of eggs is significant: $r=+0.62(0.02<p<0.05)$ and $r=+0.67$ $(0.01<\mathrm{p}<0.02)$, respectively (figs. $10 \mathrm{~A}, \mathrm{C})$. There is no linear correlation between $\mathrm{B} / \mathrm{C}$ and the number of eggs (fig. 10B) : $\mathrm{r}=-0.44$ $(\mathrm{p}>0.1)$.

\section{Eye size}

The average of the eye diameter in high-helmeted specimens (28/ $1 / 70 ; \mathrm{N}=20)$ was $0.063 \mathrm{~mm}$ and of low-helmeted specimens $(25 / 9 / 69$; $\mathrm{N}=20$ ) was $0.055 \mathrm{~mm}$. The difference between the means is significant $(\mathrm{t}=3.17 ; 0.001<\mathrm{p}<0.01)$.

\section{I S C U S S I O N}

Zaret (1972) suggests that in tropical regions occur polymorphism with cohabitation of forms and no cyclomorphosis. The present work is not based on the study of spatial distribution of the species but on samples collected in one station in the middle of the reservoir. Nevertheles, the results based on a significant number of specimens seem to show a certain coherence in the variation of the proportions of the structures, pointing out to the existence of a variation in time. In the future there is a plan to carry on the research on the theme, including the spatial distribution, having in view the confirmation of the results obtained here.

The pattern of variation of the relative length of the helmet and of the spine are similar in each one of the instars, as well as between the two instars. There are few data concerning the relative length of the spine, but the results presented differ from the related by Brooks and Hsi Ming (in Hazelwood, 1962) that observed an inverse relationship between the ratios spine/carapace and head/carapace.

The head always presented an apical lengthening (helmet), and the rounded form was not found. From the two regions of the head, the one that seems more sensitive to the considered factors is the helmet, agreeing with the results obtained by Jacobs (1961b) in experiments with $D$. galeata mendotae.

Concerning the prenatal relative growth, generally speaking, the authors agree that temperature is an important factor. Coker and Addlestone (1938), Brooks (1946), Jacobs (1961a), and Egloff (1968) detected its influence upon the head development during the embryonic period. Differing from the results presented by these authors, in relation to other species, there is no linear correlation between the relative growth of the helmet and of the spine of $D$. gessneri and the temperature, in the embryonic phase. In the same way, the ratios $\mathrm{E} / \mathrm{C}$ and $\mathrm{S} / \mathrm{C}$ of the adults are not linearly related with this factor. On the other hand, the increase of $\mathrm{E} / \mathrm{C}$ and $\mathrm{S} / \mathrm{C}$, in the newborns and adults, when the temperature reached values higher than $25^{\circ} \mathrm{C}$, suggests the influence of this factor above the mentioned limit. The existence of a limit of temperature was observed by Brooks (1946) related to D. retrocurva in Bantam Lake; 
tachyauxesis of the post natal growth of the head occurred at temperatures above $19^{\circ} \mathrm{C}$.

Other factor to consider in Americana Reservoir is turbulence. In 1969, the dry season was exceptionally intense from April to October. The following summer rains were particularly strong and the intensification of the drainage of Atibaia River could have increased the turbulence in the reservoir. Independently of this year, an increase of the river drainage during the wet season (October-March) always occurs. Mainly concerning postnatal growth, turbulence seems to be an important factor (Brooks, 1947; Hrbácek, 1959). Jacobs (1961a) detected its influence in experiments at $14^{\circ} \mathrm{C}$, on the postnatal as well as on the prenatal growth of $D$. galeata mendotae, considering, however, difficult to extend this conclusion to the natural environment.

The influence of nutrition, supported by Woltereck, is controversial, and Brooks (1946) do not believe it to be related with the pre and postnatal growth of the head. Jacobs (1961a), nevertheless, ascertained that starvation had a depressor effect on the relative growth rate, at $24^{\circ} \mathrm{C}$. Concerning $D$. gessneri nutrition seems to have influenced the development of the helmet and spine in the two stages, during the observed period. However, in opposition to temperature and turbulence, the existence of cyclic variation of available food in the reservoir is not evident, the influence of nutrition, as a isolated factor, upon the cyclomorphosis of $D$. gessneri being questionable. In September, 1969, occurred a water bloom of the blue green alga Anabaena spiroides, what seems to have affected the relative growth. On that occasion, the substances excreted by the algae affected either directly the development or indirectly through the influence on the organisms suitable as food. It is hard to assert with certainty, but the occurrence of ephippial females in relatively large numbers on that occasion (Zago, 1976), could be a sign of starvation (Hutchinson, 1967).

As Brooks (1946) and Jacobs (1961a) suggest, mainly in relation to the postnatal growth, but which in this work may also apply to the prenatal growth, the cyclomorphosis of gessneri could be the result not from the action of a single factor, but from the joint action of some factors as temperature, turbulence and nutrition. Brooks (in Hazelwood, 1962 ) verified that in $D$. longiremis the cyclomorphosis is the result of the influence of temperature and turbulence.

The structural variations presented by gessneri are, however, not as pronounced as compared with species from temperate regions.

With regard to the eye, the results are contrary to those obtained by Zaret (1972) with other species of Daphnia. In gessneri the high helmeted form has a bigger eye. Nevertheless, the difference is small, the reduction in the low helmeted form being of 12,7 per cent. Anyway, this difference seems to be very small to be distinguished by predators.

\section{I T E R A T UR E}

BROOKS, J. L. - 1946 - Cyclomorphosis in Daphnia. I. An analysis of D. retrocurva and D. galeata. Ecol. Monogr., 16 (4): 409-447. 
BROOKS, J. L. - 1947 - Turbulence as an environmental determinant of relative growth in Daphnia. Proc. Nat. Acad. Sci., 33: 141-148.

BROOKS, J. L. - 1965 - Predation and relative helmet size in cyclomorphic Daphnia. Proc. Nat. Acad. Sci. U.S., 53: 119-126.

COKER, R. E. and H. H. ADDLESTONE - 1938 - Influence of temperature on cyclomorphosis in Daphnia longispina. J. Elisha Mitchell Sci. Soc., 54: 45-75.

DODSON, S. I. - 1974 - Adaptive change in plankton morphology in response to size-selective predation: A new hypothesis of cyclomorphosis. Limnol. Oceanogr., 19 (5): 721-729.

EGLOFF, D. A. - 1968 - The relative growth and seasonal variation of several cyclomorphic structures of Daphnia catawba Coker in natural populations. Arch. Hydrobiol., 65 (3): 325-359.

GREEN, J. - 1956 - Growth, size and reproduction in Daphnia (Crustacea-Cladocera). Proc. Zool. Soc. Lond., 126: 173-204.

GREEN, J. - 1967 - The distribution and variation of Daphnia lumholtzi (CrustaceaCladocera) in relation to fish predation in Lake Albert, East Africa. Proc. Zool. Soc. Lond., 151: 181-197.

HAZELWOOD, D. H. - 1962 - Temperature and photoperiod effects on cyclomorphosis in Daphnia. Limnol. Oceanogr., 7 (2): 230-232.

HAZELWOOD, D. H. - 1966 - Illumination and turbulence effects on relative growth in Daphnia. Limnol. Oceanogr., 11 (2): 212-216.

HRBĀCEK, J. - 1959 - Circulation of water as a main factor influencing the development of helmets in Daphnia cucullata Sars. Hydrobiologia, 13: 170-186.

HUTCHINSON, G. E. - $1967-A$ Treatise on Limnology 2: Introduction to Lake Biology and the Limnoplankton. New York, John Wiley \& Sons, Inc. $1115 \mathrm{pp}$.

JACOBS, J. - 1961a - Cyclomorphosis in Daphnia galeata mendotae Birge, a case of environmentally controlled allometry. Arch. Hydrobiol., 58: 7-71.

JACOBS, J. - 1961b - On the regulation mechanism of environmentally controlled allometry (heterauxesis) in cyclomorphic Daphnia. Physiol. Zool., 34: 202-216.

JACOBS, J. - 1962 - Light and turbulence as co-determinants of relative growth rates in cyclomorphic Daphnia. Int. Rev. ges. Hydrobiol., 47: 146-156.

JACOBS, J. - 1967 - Untersuchungen zur Funktion und Evolution der Zyklomorphose bei Daphnia, mit besonderer Berücksichtigung der Selektion durch Fische. Arch. Hydrobiol., 62 (4): 467-541.

OSTWALD, W. - 1904 - Experimentele Untersuchungen über den Saisonpolymorphismus bei Daphniden. Arch. Entwick. Mech., 18: 415-451.

WESENBERG-LUND, C. - 1926 - Contribution to the biology and morphology of the genus Daphnia. K. Danske Vidensk. Selsk. Skr., Natur. Mathem., 11 (2): 91-250.

WOLTERECK, R. - 1909 - Weitere experimentele Untersuchungen über Artveränderung, speziel über das Wesen quantitativer Artunterschiede bei Daphniden. Verh. Zool. Ges., 19: 110-172.

ZAGO, M. S. A. - 1976 - The planktonic Cladocera (Crustacea) and aspects of the 1 entrophication of Americana Reservoir (Brazil). Bolm. Zool., 1: 105-145.

ZARET, T. M. - 1972 - Predators, invisible prey, and aspects of polymorphism in the Cladocera (class Crustacea). Limnol. Oceanogr., 17 (2): 171-184.

Adress: Departamento de Zoologia, Instituto de Biociências, Universidade de São Paulo. Caixa Postal 20.520, São Pauło, Brasil. 